\title{
Dissimilatory Sulphur Metabolism in Phototrophic 'Non-sulphur' Bacteria
}

\author{
By OTMAR NEUTZLING, CORNELIA PFLEIDERER AND \\ HANS G. TRÜPER* \\ Institut für Mikrobiologie der Rheinischen Friedrich-Wilhelms-Universität, \\ Meckenheimer Allee 168, D-5300 Bonn, Federal Republic of Germany
}

(Received 24 August 1984; revised 12 November 1984)

\begin{abstract}
Four species of the purple 'non-sulphur' bacteria (Rhodospirillaceae) were examined with respect to their dissimilatory sulphur metabolism. Under anaerobic conditions with $\mathrm{CO}_{2}$ as sole carbon source, cell suspensions of Rhodopseudomonas sulfoviridis, Rhodobacter veldkampii and Rhodobacter adriaticus, all dependent on reduced sulphur compounds for growth, oxidized sulphide to an intermediate compound (elemental sulphur, possibly polysulphides) that was converted either partly ( $R$. veldkampii) or completely into sulphate, whereas thiosulphate oxidation occurred without detectable intermediates. In contrast, Rhodobacter sulfidophilus oxidized sulphide as well as thiosulphate to sulphate. Both oxidations occurred with simultaneous excretion of sulphate and sulphite; the latter was subsequently also transformed into sulphate. In cell-free extracts the presence of a reverse sulphite reductase could not be proven. An adenosine 5 '-phosphosulphate (APS) reductase could not be detected either, but all strains contained a membrane-bound sulphite oxidoreductase that is obviously responsible for sulphate production. This enzyme was solubilized and partly purified from $R$. adriaticus, Rps. sulfoviridis and $R$. sulfidophilus.
\end{abstract}

\section{INTRODUCTION}

After the account of Molisch (1907) it was assumed that the purple non-sulphur bacteria (Rhodospirillaceae; throughout the paper the new nomenclature of the phototrophic non-sulphur bacteria, as proposed by Imhoff et al., 1984, is used) were only capable of assimilatory sulphur metabolism: sulphide was supposed to be toxic for them. van Niel (1944) noticed the ability of Rhodopseudomonas palustris to use thiosulphate; sulphide as photosynthetic electron donor for Rhodomicrobium vannielii was first mentioned by van Niel (1963). Hansen \& van Gemerden (1972) demonstrated the ability of several species of Rhodospirillaceae to use sulphide as electron donor, when they were grown in a sulphide-limited chemostat. These authors found that Rhodospirillum rubrum, Rhodobacter capsulatus and Rhodobacter sphaeroides oxidized sulphide only to elemental sulphur, whereas Rps. palustris converted sulphide to sulphate without measurable intermediates. During the following years an increasing number of Rhodospirillaceae were isolated that not only showed remarkable sulphide tolerance, like Rhodobacter sulfidophilus (Hansen \& Veldkamp, 1973), but were even dependent on reduced sulphur compounds, namely Rhodopseudomonas sulfoviridis (Keppen \& Gorlenko, 1975), Rhodobacter veldkampii (Hansen et al., 1975; Hansen \& Imhoff, 1985) and Rhodobacter adriaticus (Neutzling et al., 1984). These species perform a dissimilatory sulphur metabolism comparable to that of phototrophic sulphur bacteria. But little is known about intermediates and enzymes involved in sulphur oxidation of the phototrophic 'non-sulphur' bacteria.

The present paper reports studies on four species ( $R$. sulfidophilus, Rps. sulfoviridis, $R$. veldkampii and $R$. adriaticus) of purple 'non-sulphur' bacteria with respect to their dissimilatory sulphur metabolism.

Abbreviation: APS, adenosine 5'-phosphosulphate. 


\section{METHODS}

Bacteria. Rhodobacter sulfidophilus W4 (DSM 1374) and Rhodobacter veldkampii 51 (ATCC 35703) were obtained from Dr T. A. Hansen, University of Groningen, The Netherlands, and Rhodopseudomonas sulfoviridis Pl (DSM 729) from the Deutsche Sammlung für Mikroorganismen, Göttingen, FRG; Rhodobacter adriaticus 6II (DSM 2781) was isolated in this department (Neutzling et al., 1984).

Growth conditions. Cells were grown in the following basal medium, containing in 1 litre: $1 \mathrm{~g} \mathrm{KH}_{2} \mathrm{PO}_{4}, 0 \cdot 1 \mathrm{~g}$ $\mathrm{CaCl}_{2} .2 \mathrm{H}_{2} \mathrm{O}, 0.5 \mathrm{~g} \mathrm{MgCl}_{2} .6 \mathrm{H}_{2} \mathrm{O}, 1 \mathrm{~g} \mathrm{NH}_{4} \mathrm{Cl}, 3 \mathrm{~g} \mathrm{NaHCO}_{3}, 0.5 \mathrm{~g}$ sodium ascorbate, $1 \mathrm{ml}$ vitamin solution ' $\mathrm{VA}$ ', as described by Imhoff \& Trüper (1977). For stock cultures $0.82 \mathrm{~g}$ sodium acetate and $0.1 \mathrm{~g}$ yeast extract per litre were added. In addition the following ingredients were added per litre. $R$. sulfidophilus: $25 \mathrm{~g} \mathrm{NaCl}, 1 \mathrm{ml}$ trace element solution 'SL4', as described by Pfennig \& Lippert (1966), and $0.24 \mathrm{~g} \mathrm{Na}_{2} \mathrm{~S} .9 \mathrm{H}_{2} \mathrm{O}, 0.25 \mathrm{~g} \mathrm{Na}_{2} \mathrm{~S}_{2} \mathrm{O}_{3} .5 \mathrm{H}_{2} \mathrm{O}$ or $0.24 \mathrm{~g} \mathrm{Na}_{2} \mathrm{SO}_{4}$ as sulphur sources; Rps. sulfoviridis: $1 \mathrm{ml}$ trace element solution 'SLA', as described by Imhoff \& Trüper (1977), and $0.24 \mathrm{~g} \mathrm{Na} 2 \mathrm{~S} .9 \mathrm{H}_{2} \mathrm{O}, 0.25 \mathrm{~g} \mathrm{Na}_{2} \mathrm{~S}_{2} \mathrm{O}_{3} .5 \mathrm{H}_{2} \mathrm{O}$ or $0.12 \mathrm{~g}$ cysteine as sulphur sources; $R$. veldkampii: $1 \mathrm{ml}$ trace element solution 'SL4' and $0.24 \mathrm{~g} \mathrm{Na} 2 \mathrm{~S} .9 \mathrm{H}_{2} \mathrm{O}, 0.125 \mathrm{~g} \mathrm{Na} \mathrm{S}_{2} \mathrm{O}_{3} .5 \mathrm{H}_{2} \mathrm{O}$ or $0.06 \mathrm{~g}$ cysteine as sulphur sources. Growth conditions for $R$. adriaticus, photolithoautotrophic growth, and determination of sulphide, thiosulphate, elemental sulphur, sulphate, and protein of whole cells and cell-free extracts have been described earlier (Neutzling et al., 1984). Sulphite was determined by an enzyme assay employing sulphite oxidase and NADH peroxidase (Boehringer test combination no. 725854).

Experiments with cell suspensions. These were done anaerobically in a $100 \mathrm{ml}$ glass vessel, flushed with oxygenfree nitrogen as described by Neutzling \& Trüper (1982).

Enzyme assays. For enzyme tests cells were harvested, suspended in $50 \mathrm{mM}-\mathrm{Tris} / \mathrm{HCl}$ buffer, $\mathrm{pH} 8 \cdot 0$, and disrupted by passing them twice through a French press $(110 \mathrm{MPa})$. Cell debris was removed by centrifugation at 15000 r.p.m. for $15 \mathrm{~min}$ (Sorvall RC5); the supernatant was defined as 'crude extract'. After centrifugation of the crude extract at $105000 \mathrm{~g}$ in a Beckman ultracentrifuge two fractions were obtained: the supernatant was termed 'soluble protein' the pellet 'membrane fraction'.

Sulphite reductase (EC 1.8.99.1) assays with hydrogenase were done according to Yoshimoto \& Sato (1968); sulphite reductase assays with electrochemical reduction of methyl viologen, and APS reductase (AMP, sulphite :ferricyanide oxidoreductase, EC 1.8.99.2) assays have been described earlier (Neutzling et al., 1984). Sulphite oxidoreductase (sulphite:ferricytochrome $c$ oxidoreductase, EC 1.8.2.1) assays contained in $1 \mathrm{ml}$ : $50 \mu \mathrm{mol} \mathrm{Tris} / \mathrm{HCl} \mathrm{pH} \mathrm{8.0,} 5 \mu \mathrm{mol}$ EDTA, $1 \mu \mathrm{mol} \mathrm{K}{ }_{3}\left(\mathrm{Fe}(\mathrm{CN})_{6}\right)$ and $5 \mu \mathrm{mol} \mathrm{Na}_{2} \mathrm{SO}_{3}$. Decrease in the absorbance at $420 \mathrm{~nm}$ indicated enzyme activity $\left(\varepsilon_{420}\right.$ ferricyanide $=1.0$ litre $\left.\mu \mathrm{mol}^{-1} \mathrm{~cm}^{-1}\right)$. After subtraction of sulphiteindependent reduction, rates of ferricyanide specific activity were expressed as $\mathrm{mU}\left(\mathrm{mg}\right.$ protein) ${ }^{-1}$, where $1 \mathrm{mU}$ $=0.5 \times 10^{3} \cdot \Delta A_{420} \mathrm{~min}^{-1}$. Sulphite oxidoreductase assay with cytochrome $c$ as electron acceptor was performed according to Trüper \& Rogers (1971).

Enzyme purification and characterization. Protein solutions were desalted by passing them through a Sephadex G25 column, equilibrated in $10 \mathrm{~mm}-\mathrm{Tris} / \mathrm{HCl}, \mathrm{pH} 8.0$. For enzyme purification ion exchange chromatography (Whatman DEAE 52 cellulose in $10 \mathrm{mM}$-Tris/ $\mathrm{HCl}, \mathrm{pH} 8.0$ ), elution with a continuous $\mathrm{NaCl}$ gradient $(0-400 \mathrm{mM}$ ) and gel filtration (Sephacryl S-300, equilibrated in $50 \mathrm{mM}-\mathrm{Tris} / \mathrm{HCl}, \mathrm{pH} 8.0$, containing $100 \mathrm{mM}-\mathrm{NaCl}$ ) were used. Triton X-100 was removed by passage through a column filled with BioBeads SM2, according to the method of Holloway (1973).

Molecular weights were determined by gel filtration through a Sephacryl S-300 column $(2 \times 60 \mathrm{~cm})$, using the Boehringer Combithek no. 104558 with ferritin, catalase, bovine serum albumin, hen egg albumin, chymotrypsinogen $\mathrm{A}$ and horse heart cytochrome $c$ as marker proteins.

Isoelectric points were determined by flat bed electrophoresis in an LKB Multiphor 2117, using polyacrylamide gels $(5 \%, w / v)$ with a final $\mathrm{pH}$ range of $3 \cdot 5-9 \cdot 0$.

\section{RESULTS AND DISCUSSION}

\section{Experiments with cell suspensions}

Fig. 1 (a) demonstrates anaerobic sulphide oxidation by a cell suspension of Rhodobacter sulfidophilus. A biphasic oxidation cannot be seen; sulphide consumption correlated with sulphate production. Small amounts of sulphite were excreted during oxidation, but after a significant decrease in sulphide concentration, this sulphite was transformed into sulphate also. No thiosulphate was consumed during the experiment, because the ability to oxidize thiosulphate is not constitutive (Hansen, 1974). If thiosulphate was the only electron donor, however, $R$. sulfidophilus showed a rapid oxidation of this compound with simultaneous production of sulphate and sulphite (Fig. $1 b$ ); the latter was subsequently oxidized to sulphate, too. Cell suspensions with lower protein concentrations, exhibiting much slower oxidation rates, 


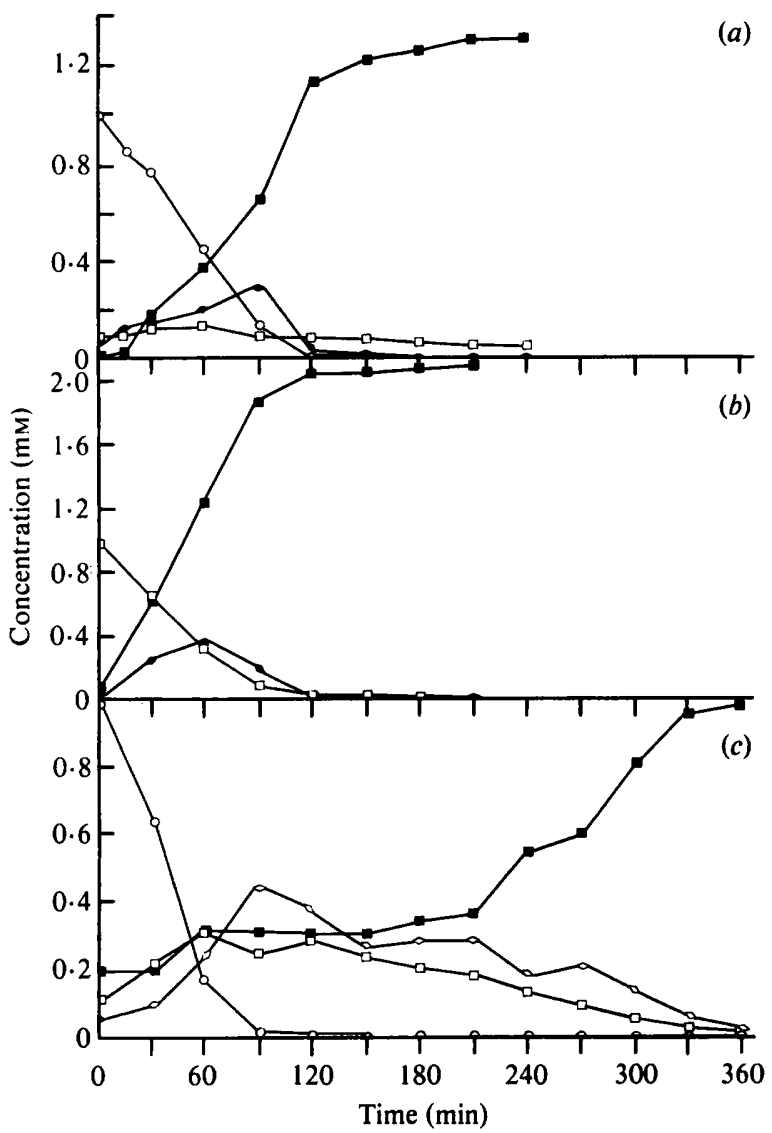

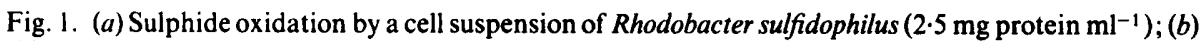
thiosulphate oxidation by a cell suspension of Rhodobacter sulfidophilus $\left(4.2 \mathrm{mg}\right.$ protein $\left.\mathrm{ml}^{-1}\right) ;(c)$ sulphide oxidation by a cell suspension of Rhodopseudomonas sulfoviridis $\left(1.8 \mathrm{mg}\right.$ protein $\left.\mathrm{ml}^{-1}\right)$. All experiments were done under anaerobic conditions with $\mathrm{CO}_{2}$ as sole carbon source. Cells were previously grown under photoheterotrophic conditions (stock culture with $1 \mathrm{~mm}$-sulphide in $a$, and $1 \mathrm{~mm}$-thiosulphate in $b$ ), harvested, washed and resuspended in fresh medium. The curves represent typical results of several series of experiments. $O$, Sulphide; $\square$, thiosulphate; $\square$, sulphate; $\diamond$, sulphite; $\diamond$, elemental sulphur or polysulphides.

excreted sulphite and sulphate in equimolar amounts. Sulphite as sole electron donor was insufficient; it was only consumed if sulphide or thiosulphate were also present in the medium.

The same types of experiments were done with cell suspensions of Rhodopseudomonas sulfoviridis. In this case, sulphide oxidation was biphasic (Fig. 1c): sulphide was taken up quickly and converted into a still unknown compound that gave a positive reaction in the elemental sulphur assay. Globules of elemental sulphur, however, were never detected during growth, as has already been described by Keppen \& Gorlenko (1975). If sulphide-grown cells were disrupted and centrifuged, the pellet often contained sulphur globules. We therefore assume that Rps. sulfoviridis forms polysulphides within the cytoplasm or in the periplasmic space, which coalesce to form globules during centrifugation and in contact with air are oxidized to elemental sulphur. After consumption of sulphide, the intracellular polysulphides are subsequently oxidized to sulphate. Polysulphides as intermediate products in sulphide oxidation of several Thiobacillus species have already been discussed (Moriarty \& Nicholas, 1970; Aminuddin \& Nicholas, 1973; Schedel, 1978). If colloidal elemental sulphur was offered as the only electron and sulphur source, sulphide appeared after a short time. Later sulphate could be detected in the medium (data not shown). This indicates that oxidation is preceded by an initial reduction of the elemental sulphur. 
Thiosulphate oxidation occurred without a measurable intermediate. Both sulphur atoms (sulphane and sulphone sulphur) were oxidized to sulphate. In this respect Rps. sulfoviridis, Rhodobacter veldkampii and Rhodobacter adriaticus gave identical results (Neutzling et al., 1984).

$R$. veldkampii was the first species within the Rhodospirillaceae that was found to be able to oxidize elemental sulphur partly to sulphate (Hansen et al., 1975). With cell suspensions of this organism we found the same results, i.e. sulphide was taken up very quickly and converted into elemental sulphur. The medium also contained a certain amount of polysulphides, originating from a chemical reaction of sulphur with surplus sulphide. These polysulphides disappeared very quickly, too. The end products were elemental sulphur and sulphate (data not shown). When Hansen et al. (1975) grew this organism in a sulphide-limited chemostat, sulphide was directly oxidized to sulphate, and elemental sulphur was not detected. It is also known from bacteria with extracellular deposition of elemental sulphur, such as the Chlorobiaceae and Ectothiorhodospiraceae, that this sulphur was only further oxidized after sulphide had disappeared from the medium (Trüper, 1978). We therefore assume that intermediate production of elemental sulphur, sulphite or polysulphides in the Rhodospirillaceae is subject to a regulatory mechanism caused by higher concentrations of external sulphide. If elemental sulphur was offered as sole electron source right from the beginning, $R$. veldkampii oxidized this compound slowly to sulphate.

$R$. adriaticus also showed production of elemental sulphur. This sulphur was completely converted into sulphate, after the concentration of sulphide had decreased significantly (Neutzling et al., 1984). Elemental sulphur as sole electron source was only partly oxidized to sulphate. In these cultures sulphide could not be detected.

New patterns of sulphide oxidation were demonstrated. Hansen (1974) reported that Rhodomicrobium vannielii formed tetrathionate as the major end product if grown in a sulphidelimited chemostat. Our investigations show that phototrophic sulphur oxidation is much more diverse. Rhodobacter sulfidophilus is the first species of the phototrophic bacteria found to excrete sulphite during photolithotrophic growth on reduced sulphur compounds. On the basis of our experiments this sulphite production was due to regulatory effects. In the case of sulphide oxidation it seems obvious that the sulphite oxidizing enzyme was unable to follow the rapid sulphide consumption. Possibly sulphide had an inhibitory influence on these enzyme systems. During thiosulphate oxidation sulphite excretion was due to thiosulphate splitting. Either sulphone sulphur was oxidized to sulphate, and sulphane sulphur only to sulphite, which was excreted as in the case of sulphide oxidation, or sulphone sulphur was deposited outside the cells as sulphite, and the sulphane sulphur was oxidized directly to sulphate.

Cell suspensions of $R$. sulfidophilus and Rps. sulfoviridis showed a significant decrease in the oxidation rates of reduced sulphur compounds if acetate $(10 \mathrm{mM})$ was present in the medium, a result which was also found with Rhodobacter capsulatus (Wijbenga \& van Gemerden, 1981). The authors supposed a competition between acetate and sulphide for an oxidized electron acceptor, probably $\mathrm{NAD}^{+}$. After consumption of the acetate, $R$. sulfidophilus and $R p s$. sulfoviridis oxidized residual sulphide and thiosulphate, which had not been used for assimilatory purposes, to sulphate.

\section{Enzymes}

Sulphite reductase. From autotrophically grown cells of Chromatium vinosum (Schedel et al., 1979) and Thiobacillus denitrificans (Schedel \& Trüper, 1979) a reverse sulphite reductase has been purified that is obviously responsible for sulphide or elemental sulphur oxidation to sulphite. Crude extracts of the Rhodospirillaceae strains we examined showed a certain 'activity', i.e. production of sulphide, if tested with a hydrogenase-dependent system, but attempts to purify one distinct enzyme were unsuccessful: either a correlation between sulphide production and protein concentration was not detectable, or sulphide production was found even after extracts had been boiled. We therefore applied a different assay system using electrochemical reduction of methyl viologen, but sulphite-dependent oxidation of this dye could not be detected. Therefore it appears unlikely that these species of Rhodospirillaceae contain enzymes comparable to those of $C$. vinosum and $T$. denitrificans. A sulphite reductase has indeed been 
Table 1. Specific activities [ $m U$ ( $m g$ protein $\left.)^{-1}\right]$ of sulphite oxidoreductase in Rhodospirillaceae grown under various conditions

These results are representative data from several experiments. S. pr., soluble protein fraction (desalted, in $10 \mathrm{~mm}$-Tris $/ \mathrm{HCl}, \mathrm{pH} 8.0$ ); membrane, membrane fraction (in $10 \mathrm{~mm}-\mathrm{Tris} / \mathrm{HCl}, \mathrm{pH} \mathrm{8.0)}$ ). -, No activity found.

\begin{tabular}{|c|c|c|c|c|c|c|c|c|}
\hline \multirow[b]{2}{*}{ Medium* } & \multicolumn{2}{|c|}{ 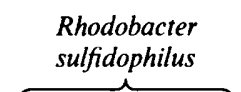 } & \multicolumn{2}{|c|}{$\begin{array}{c}\begin{array}{c}\text { Rps. } \\
\text { sulfoviridis }\end{array} \\
\underbrace{2}\end{array}$} & \multicolumn{2}{|c|}{$\begin{array}{c}\begin{array}{c}\text { Rhodobacter } \\
\text { veldkampii }\end{array} \\
\end{array}$} & \multicolumn{2}{|c|}{$\begin{array}{c}\begin{array}{c}\text { Rhodobacter } \\
\text { adriaticus }\end{array} \\
\end{array}$} \\
\hline & S. pr. & Membrane & S. pr. & Membrane & S. pr. & Membrane & S. pr. & Membrane \\
\hline $\mathrm{Ac} / \mathrm{S}^{2-}$ & 0.9 & 1.6 & 0.8 & $16 \cdot 1$ & - & $15 \cdot 0$ & - & $8 \cdot 3$ \\
\hline $\mathrm{Ac} / \mathrm{S}, \mathrm{O}_{3}^{2-}$ & 1.6 & $9 \cdot 1$ & - & $2 \cdot 8$ & - & - & - & - \\
\hline $\mathrm{Ac} / \mathrm{SO}_{4}^{2-}$ & 0.7 & - & & & & & & \\
\hline Ac/Cys & & & $2 \cdot 5$ & 7.9 & - & $19 \cdot 2$ & 0.7 & - \\
\hline $\mathrm{HCO}_{3}^{-} / \mathrm{S}^{2-}$ & 0.8 & $19 \cdot 8$ & $1 \cdot 3$ & $56 \cdot 0$ & 3.0 & 13.7 & $3 \cdot 3$ & $20 \cdot 0$ \\
\hline $\mathrm{HCO}_{3}^{-} / \mathrm{S}_{2} \mathrm{O}_{3}^{2-}$ & 0.8 & 2.9 & 0.8 & $18 \cdot 2$ & $2 \cdot 7$ & $3 \cdot 6$ & 1.6 & $11 \cdot 4$ \\
\hline
\end{tabular}

found in extracts of various species of Rhodospirillaceae, but it seemed to function only in assimilatory sulphur metabolism (Peck et al., 1974). On the other hand, $c$-type cytochromes and flavocytochromes (Trüper \& Fischer, 1982; Then \& Trüper, 1983) have been discussed as being sulphide :acceptor oxidoreductases, catalysing sulphide oxidation to elemental sulphur and thiosulphate. By comparison of cytochrome patterns of heterotrophically and autotrophically grown cells of $R$. sulfidophilus we have found that only the latter contained cytochrome $c_{551}$ and significantly higher amounts of cytochrome $c^{\prime}$ (unpublished results). The function of these cytochromes is as yet unknown. It is unlikely that they are sulphide :acceptor oxidoreductases, because $R$. sulfidophilus never produced elemental sulphur.

APS reductase. The absence of APS reductase in $R$. sulfidophilus and $R$. adriaticus has already been reported (Hansen \& Veldkamp, 1973; Neutzling et al., 1984). This enzyme could not be detected in extracts from Rps. sulfoviridis and $R$. veldkampii either. So these results correspond with the suggestion of Trüper and Peck (1970) that the absence of this enzyme is a characteristic difference from species of Chromatiaceae.

Sulphite oxidoreductase. Hansen \& Veldkamp (1973) reported the presence of an AMP independent sulphite oxidoreductase in the soluble protein fraction of $R$. sulfidophilus W4 $\left.\left[0.016 \mu \mathrm{mol} \text { sulphite } \mathrm{min}^{-1} \text { (mg protein }\right)^{-1}\right]$. Our investigations clearly demonstrate that this activity is due to low molecular weight compounds because: $(a)$ after desalting the specific activity decreased drastically; $(b)$ activity even remained after boiling for $10 \mathrm{~min}$; and $(c)$ after filtering through a Diaflo UM 2 filter (exclusion of all compounds above mol. wt 2000) 'activity' was detected in the ultrafiltrate.

In all strains, however, we found the main activity of sulphite oxidoreductase in the membrane fraction. Table 1 shows the specific activities of this enzyme in cells grown under various conditions. In the soluble protein fractions we could measure only very low activities [ $<5 \mathrm{mU}$ (mg protein $)^{-1}$ ]. The results show that cells grown autotrophically with sulphide contained significantly higher specific activities than cells grown heterotrophically with sulphide. Therefore we assume that this enzyme plays an important role in dissimilatory sulphur metabolism of these species. Low activities of this enzyme have been reported for some thiosulphate-grown species of Rhodospirillaceae, but were only measured in crude extracts (Keppen et al., 1980). R. veldkampii did not exhibit a clear correlation between growth condition and specific activity of sulphite oxidoreductase. But this organism produced mainly elemental sulphur during sulphide oxidation in batch culture. Elemental sulphur, however, was only oxidized to sulphate if it was the only electron donor. Better results could probably be obtained if this strain were grown photolithoautotrophically with elemental sulphur or in a sulphide-limited chemostat. 


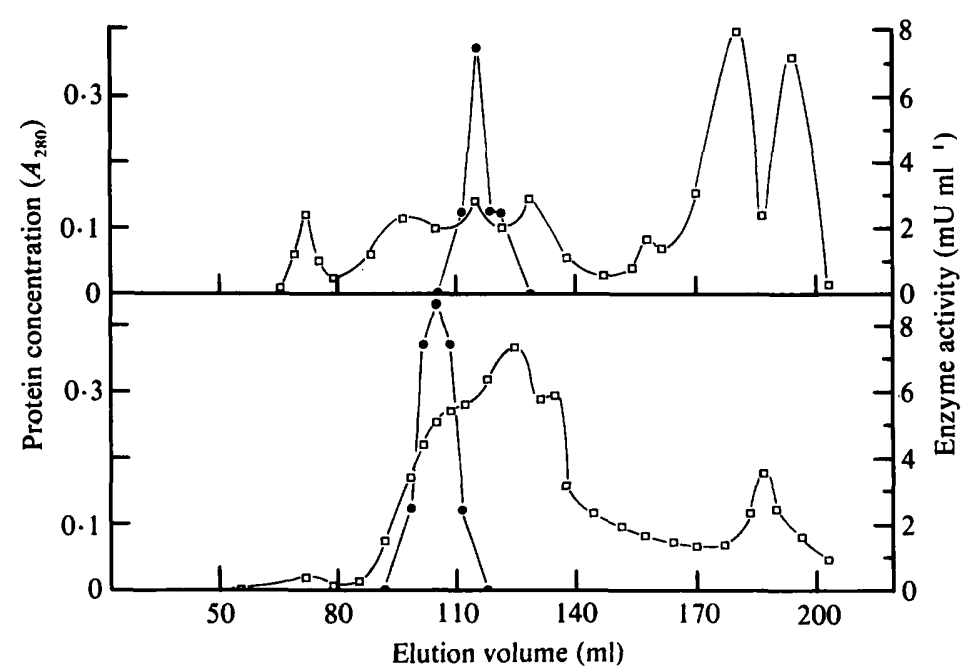

Fig. 2. Elution of Rhodobacter adriaticus sulphite oxidoreductase from Sephacryl S-300. Fractions from DEAE 52 cellulose columns, containing activity, were loaded on a Sephacryl S-300 column and eluted with $50 \mathrm{~mm}-\mathrm{Tris} / \mathrm{HCl}, \mathrm{pH} 8.0$, containing $100 \mathrm{~mm}-\mathrm{NaCl}$. Protein concentration ( $\square$ ) and enzyme activity (O) were measured. The solubilized enzyme (upper curve) eluted later, revealing a lower molecular weight than the soluble (lower curve) one.

From membrane fractions of sulphide-grown cells of $R$. adriaticus, Rps. sulfoviridis and $R$. sulfidophilus we partly purified the sulphite oxidoreductase using the following steps: (1) treatment with $1 \%(\mathrm{v} / \mathrm{v})$ Triton X-100 for $10 \mathrm{~min}$ at $37^{\circ} \mathrm{C}$; (2) removal of Triton X-100 with BioBeads SM 2 (except Rps. sulfoviridis); (3) ion exchange chromatography (DEAE52 cellulose); (4) gel filtration with Sephacryl S-300. In all cases the enzyme was solubilized, but the purification yield was poor. Sulphite oxidoreductase from $R$. sulfidophilus seemed to aggregate after removal of Triton X-100; the specific activity decreased drastically, and the enzyme eluted within the void volume of the Sephacryl S-300 column, indicating a molecular weight of more than $1.5 \times 10^{6}$. The enzyme of Rps. sulfoviridis did not adsorb to the DEAE 52 cellulose. It was eluted within the void volume together with Triton X-100. With this step we achieved the highest specific activity, but after gel filtration with Sephacryl S-300 (elution near the void volume) the specific activity decreased. So we assume that this enzyme formed aggregates, too. The best results were obtained with $R$. adriaticus sulphite oxidoreductase; here the enzyme could also be partly purified from the soluble protein fraction (see Table 2). During gel filtration with Sephacryl S-300 the soluble and the solubilized enzyme showed different behaviour (Fig. 2), revealing different molecular weights. But both proteins exhibited similar pI values; the soluble enzyme seemed to be a dimer of the solubilized one. Aminuddin \& Nicholas (1974) purified a membrane-bound sulphite oxidoreductase from $T$. denitrificans, but the molecular weight was not determined. However, this enzyme eluted within the void volume of a Sepharose 6B column, indicating a very large size. Therefore the enzyme of $R$. adriaticus appears to be the first membrane-bound sulphite oxidoreductase for which a distinct molecular weight could be determined.

An explanation for the low specific activities of sulphite oxidoreductases in the species of Rhodospirillaceae examined here could be that ferricyanide is a poor electron acceptor; concentrations above $1 \mathrm{mM}$ were inhibitory in all cases. On the other hand the theoretical $K_{\mathrm{m}}$ value for $\boldsymbol{R}$. adriaticus sulphite oxidoreductase, calculated from kinetic data with lower concentrations of ferricyanide, would be $1.15 \mathrm{mM}$. The enzyme of this organism seemed to be less tightly bound to the membrane (about $30 \%$ of total activity was detected in the soluble protein fraction), whereas $R$. sulfidophilus and Rps. sulfoviridis appeared to contain a highly membrane-integrated enzyme. This rigid association may be due to a high content of hydrophobic regions, which may cause an aggregation of several enzyme molecules after 
Table 2. Some properties of sulphite oxidoreductases from Rhodospirillaceae compared with the Chromatium vinosum enzyme

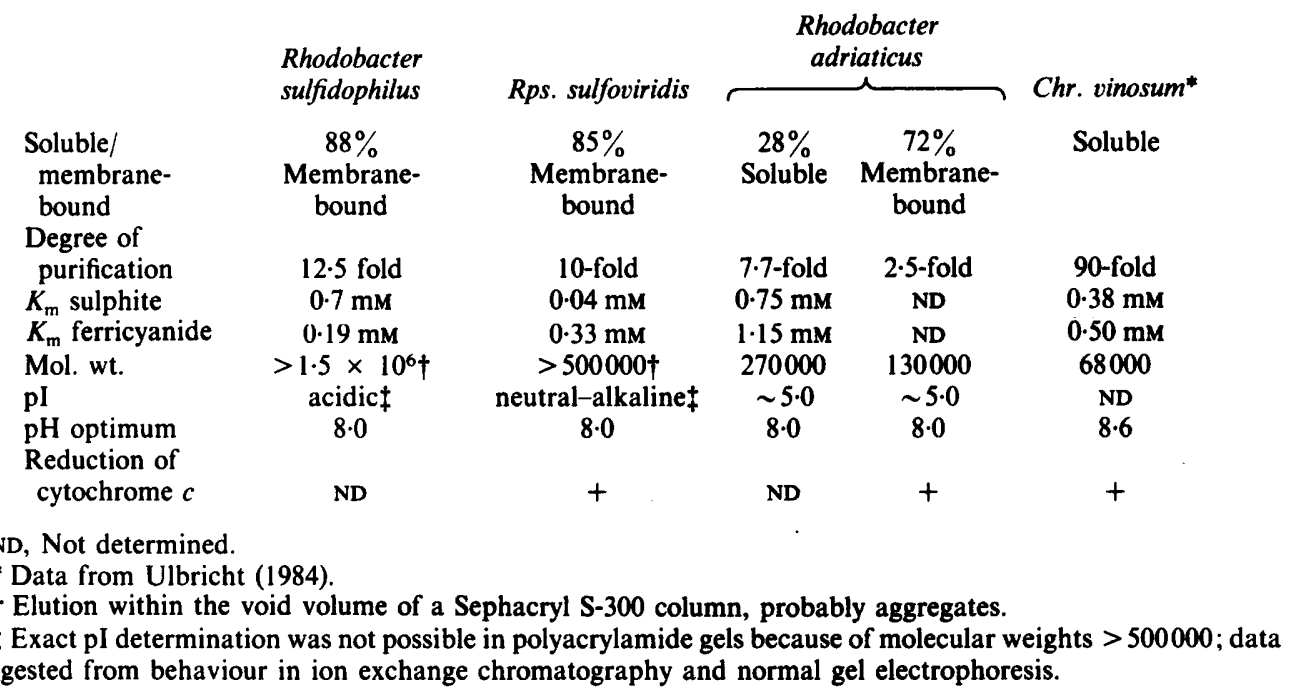

removal of the detergent, a phenomenon described for several membrane proteins; and many membrane-bound enzymes are known that require the presence of phospholipids (Steck \& Fox, 1972). The low initial activities of sulphite oxidoreductases in the species of Rhodospirillaceae we examined correlated, however, with sulphate production rates of whole cells.

If ferricyanide was replaced by cytochrome $c$ (from horse heart and Candida crusei) the results were poor: the specific activity of the $R$. adriaticus enzyme decreased 27-fold (horse heart) and 9-fold (Candida crusei), respectively, and the specific activity of the Rps. sulfoviridis enzyme decreased 67-fold (horse heart). These results appear to be common to all sulphite oxidoreductases from phototrophic bacteria examined so far (Ulbricht, 1984), whereas most Thiobacillus enzymes exhibit remarkably higher activities with cytochromes as electron acceptors (Charles \& Suzuki, 1966; Lyric \& Suzuki, 1970; Toghrol \& Southerland, 1983; Lu \& Kelly, 1984). Some of the latter proteins even contained haem constituents that were essential for enzyme activity (Toghrol \& Southerland, 1983; Lu \& Kelly, 1984). These enzymes, in contrast to those of phototrophic bacteria, are part of multi-enzyme systems which use molecular oxygen as the final electron acceptor.

This work was sponsored by a grant from the Deutsche Forschungsgemeinschaft.

\section{REFERENCES}

Aminuddin, M. \& Nicholas, D. J. D. (1973). Sulphide oxidation linked to the reduction of nitrate and nitrite in Thiobacillus denitrificans. Biochimica et biophysica acta 325, 81-93.

Aminuddin, M. \& Nicholas, D. J. D. (1974). An AMP-independent sulphite oxidase from Thiobacillus denitrificans: purification and properties. Journal of General Microbiology 82, 103-113.

Charles, A. M. \& Suzuki, I. (1966). Purification and properties of sulfite:cytochrome $c$ oxidoreductase from Thiobacillus novellus. Biochimica et biophysica acta 128, 522-534.

HANSEN, T. A. (1974). Sulfide als electrondonor voor Rhodospirillaceae. $\mathrm{PhD}$ thesis, University of Groningen.
Hansen, T. A. \& van Gemerden, H. (1972). Sulfide utilization by purple non-sulfur bacteria. Archiv für Mikrobiologie 86, 49-56.

HANSEN, T. A. \& IMHOFF, J. F. (1985). Rhodobacter veldkampii, a new species of phototrophic purple nonsulfur bacteria. International Journal of Systematic Bacteriology 35, 115-116.

HANSEN, T. A. \& VeldKAMP, H. (1973). Rhodopseudomonas sulfidophila, nov. spec., a new species of the purple non-sulfur bacteria. Archiv für Mikrobiologie 92, 45-58.

Hansen, T. A., Sepers, A. B. J. \& van Gemerden, H. (1975). A new purple bacterium that oxidizes sulfide to elemental sulfur and sulfate. Plant and Soil 43,1727. 
Holloway, P. W. (1973). A simple procedure for removal of Triton X-100 from protein samples. Analytical Biochemistry 53, 304-308.

IMHOFF, J. F. \& TRÜPER, H. G. (1977). Ectothiorhodospira halochloris, sp. nov., a new extremely halophilic phototrophic bacterium containing bacteriochlorophyll $b$. Archites of Microbiology 114, 115-121.

ImHOFF, J. F., TRüPer, H. G. \& PfenNig, N. (1984). Rearrangement of the species and genera of the photosynthetic 'purple non-sulfur bacteria'. International Journal of Systematic Bacteriology 34, 340343.

KePPEN, O. I. \& GorlenKo, V. M. (1975). A new species of purple budding bacteria containing bacteriochlorophyll b. Mikrobiologiya 44, 258-264.

Keppen, O. I., Pedan, L. V. \& Rodova, N. A. (1980). Oxidation of thiosulfate by purple nonsulfur bacteria. Mikrobiologiya 49, 682-686.

LU, W.-P. \& Kelly, D. P. (1984). Properties of sulphite: cytochrome $c$ oxidoreductase purified from Thiobacillus versutus (A2). Journal of General Microbiology 130, 1683-1692.

LYRIC, R. M. \& SUzUKI, I. (1970). Enzymes involved in the metabolism of thiosulfate by Thiobacillus thioparus. (a) Survey of enzymes and properties of sulfite : cytochrome $c$ oxidoreductase. Canadian Journal of Biochemistry 48, 334-343.

Molisch, H. (1907). Die Purpurbakterien nach neueren Untersuchungen, pp. 1-45. Jena: Gustav Fischer.

Moriarty, D. J. W. \& Nicholas, D. J. D. (1970). Products of sulphide oxidation in extracts of Thiobacillus concretivorus. Biochimica et biophysica acta 197, 143-151.

Neutzling, O. \& TRÜPER, H. G. (1982). Assimilatory sulfur metabolism in Rhodopseudomonas sulfoviridis. Archives of Microbiology 133, 145-148.

NeUtzling, O., IMHOFF, J. F. \& TRÜPER, H. G. (1984). Rhodopseudomonas adriatica sp. nov., a new species of the Rhodospirillaceae, dependent on reduced sulfur compounds. Archives of Microbiology 137, 256261.

VAN NiEL, C. B. (1944). The culture, general physio$\operatorname{logy}$, morphology and classification of the non-sulfur purple and brown bacteria. Bacteriological Reviews $\mathbf{8}$, 1-118.

VAN Niel, C. B. (1963). A brief survey of the photosynthetic bacteria. In Bacterial Photosynthesis, pp. 459-467. Edited by H. Gest, A. San Pietro \& L. P. Vernon. Yellow Springs, Ohio: Antioch Press.

PECK, H. D., JR, TEDro, S. \& Kamen, M. D. (1974). Sulfite reductase activity in extracts of various photosynthetic bacteria. Proceedings of the National Academy of Sciences of the United States of America 71, 2404-2406.
Pfennig, N. \& Lippert, K. D. (1966). Über das Vitamin $B_{12}$-Bedürfnis phototropher Schwefelbakterien. Archiv für Mikrobiologie 55, 245-256.

SCHEDEL, M. (1978). Untersuchungen zur anaeroben Oxidation reduzierter Schwefelverbindungen durch Thiobacillus denitrificans, Chromatium vinosum und Chlorobium limicola. PhD thesis, University of Bonn.

SCHEdel, M. \& TrüPER, H. G. (1979). Purification of Thiobacillus denitrificans siroheme sulfite reductase and investigation of some molecular and catalytic properties. Biochimica et biophysica acta 568, 454467.

Schedel, M., Vanselow, M. \& TrüPer, H. G. (1979). Siroheme sulfite reductase isolated from Chromatium vinosum. Purification and investigation of its molecular and catalytic properties. Archives of Microbiology 121, 29-36.

SteCK, T. L. \& Fox, C. F. (1972).. Membrane proteins.

- In Membrane Molecular Biology, pp. 27-75. Edited by C. F. Fox \& A. D. Keith. Stamford, Conn.: Sinavor Associates.

THEN, J. \& TRÜPER, H. G. (1983). Sulfide oxidation in Ectothiorhodospira abdelmalekii. Evidence for the catalytic role of cytochrome $c_{551}$. Archives of Microbiology 135, 254-258.

Toghrol, F. \& Southerland, W. M. (1983). Purification of Thiobacillus novellus sulfite oxidase. Journal of Biological Chemistry 258, 6762-6766.

TRÜPER, H. G. (1978). Sulfur Metabolism. In The Photosynthetic Bacteria, pp. 677-690. Edited by R. K. Clayton \& W. R. Sistrom. New York \& London: Plenum Press.

TRÜPER, H. G. \& FISCHER, U. (1982). Anaerobic oxidation of sulphur compounds as electron donors for bacterial photosynthesis. Philosophical Transactions of the Royal Society B298, 529-542.

TrüPER, H. G. \& PECK, H. D., JR (1970). Formation of adenylyl sulfate in phototrophic bacteria. Archiv für Mikrobiologie 73, 125-142.

TrüPer, H. G. \& Rogers, L. A. (1971). Purification and properties of adenylylsulfate reductase from the phototrophic sulfur bacterium Thiocapsa roseopersicina. Journal of Bacteriology 108, 1112-1121.

UlBRICHT, H. M. U. (1984). Aspekte des Energiegewinns durch Substratphosphorylierung im Zuge der Sulfitoxidation bei Chromatiaceae und Thiobacillus denitrificans. PhD thesis, University of Bonn.

WiJBenga, D. \& VAN Gemerden, H. (1981). The influence of acetate on the oxidation of sulfide by Rhodopseudomonas capsulata. Archives of Microbio$\log y$ 129, 115-118.

Yoshimoto, A. \& Sato, R. (1968). Studies on yeast sulfite reductase. I. Purification and characterization. Biochimica et biophysica acta 153, 555-575. 